\title{
Phytochemical Analysis and Antioxidant Potential of Raphia hookeri leaf and Epicarp
}

\section{OLUYORI PETER ABIMBOLA*, DADA ADEWUMI OLUWASOGO, and INYINBOR ABOSEDE ADEJUMOKE}

\author{
Department of Physical Sciences, Landmark University, Omu-Aran, Kwara State, Nigeria. \\ *Corresponding author E-mail: oluyori.abimbola@Imu.edu.ng \\ http://dx.doi.org/10.13005/ojc/340608
}

Received: September 19, 2018; Accepted: November 25, 2018)

\begin{abstract}
The contribution of oxidative stress to the pathogenesis of several health conditions and its association with life-threatening diseases such as malaria has necessitated the search for more phytochemicals with antioxidant properties. Various parts of Raphia hookeri such as the leaves, fruit and sap have been moderately studied and applied in different areas of industry. However, the epicarp is generally discarded. The ethanolic extracts of Raphia hookeri leaf and epicarp were herein investigated for their total phenolic and flavonoid contents using spectrometric methods. 1,1-diphenyl2-picryl hydrazyl radical (DPPH) and 2,2-azino-bis (3-ethylbenzthiazoline-6-sulfonic acid) (ABTS) cation assays were used to determine the antioxidant potential of the extracts. The recorded Total Phenolic Content (TPC) of both extracts are comparable while the Total Flavonoid Content of the leaf extract is higher. Consequently, the antioxidant activity of the leaf extract was higher. Although the antioxidant potential of the leaf is higher $(351.170 \pm 22.950 \mathrm{mg} / \mathrm{g} \mathrm{RE})$, the comparable TPC and the antioxidant activity exhibited by Raphia hookeri epicarp extract projects it as a rich phytochemical bio-resourse which may have future relevance in the pharmaceutical industry.
\end{abstract}

Keywords: Oxidative stress, Antioxidants, Raphia hookeri, Phenolics, Flavonoids, Pericarp.

\section{INTRODUCTION}

Oxidative stress is a condition in which there is an imbalance in the cellular antioxidant and reactive oxygen/reactive nitrogen species in the body and has contributed to the pathogenesis of chronic ailments such as cancer, aging and neurodegenerative diseases ${ }^{1}$. Although reactive oxygen species (ROS) exhibit defensive functions in cells, their overproduction leads to deleterious effects in cells. Particularly, oxidative stress has been associated with malaria (Plasmodium falciparum) infection during which reactive oxygen species are generated excessively in cells ${ }^{2}$. The statistics of malaria cases in sub-saharan Africa is alarming. According to $\mathrm{WHO}, 212$ million malaria cases and an estimated 429, 000 malaria-related deaths were recorded in 2015 alone $^{3}$. Furthermore, several antimalaria drugs in current use induce oxidative stress as a side effect while exerting their therapeutic effect, hence, a reason for the need for antioxidant supplements during malaria treatment ${ }^{4}$.

This is an Open Access article licensed under a Creative Commons license: Attribution 4.0 International (CC- BY). Published by Oriental Scientific Publishing Company @ 2018 
Raphia hookeri (Raffia palm) is a member of the palmaceae family which is common in West Africa Particularly, in Nigeria, Raphia hookeri thrives so well and its various parts have received wide industrial application. The leaf and the fruit (mesocarp) have been used in wine production ${ }^{5}$, inhibition of aluminium corrosion ${ }^{6}$, biosorbent ${ }^{7}$, caramel production ${ }^{8}$ while the epicarp which was usually discarded has recently reported to be useful as bioadsorbent for the treatment of textile industrial effluents ${ }^{9}$. Furthermore, several reports focused on the nutritional application of the leaf, fruit and latex of the plant ${ }^{10,11,12}$. However, to the best of our knowledge, there exists no information about the antioxidant medicinal application of the epicarp. This waste material could turn out to be a source of important phytochemicals, thus reducing the burden of environmental waste management.

Therefore, in continuation of our efforts targeted at obtaining beneficial phytochemicals from waste bioresources ${ }^{13,14,15,16}$, we herein report the comparative phytochemical analysis and the antioxidant potential of the leaf and epicarp of Raphia hookeri.

\section{MATERIALS AND METHOD}

\section{Plant material}

Raphia hookeri leaf and epicarp were collected around Landmark University and from local farmers in Makogi, Edu local government, Kwara State, Nigeria.

\section{Preparation of extract}

A total of $20 \mathrm{~g}$ dried sample of oven-dried epicarp and $18.5 \mathrm{~g}$ sample of oven-dried leaves of Raphia hookeri were macerated in $100 \mathrm{~cm}^{3}$ of absolute ethanol for 2 days at room temperature. The extraction was not done in the dark. The mixtures were filtered and the resulting extract solutions were afterwards concentrated at $60^{\circ} \mathrm{C}$ to obtain the desired extracts which were immediately analysed for their antioxidant potential.

\section{Phytochemical screening}

The extracts were screened for the presence phenolics, flavonoids and some other secondary metabolites according to established procedures $^{(20)}$.

\section{Determination of total phenolic content}

Modified folin- ciocalteu method ${ }^{17}$ was used to determine the total phenolics contents in the extracts. In brief, $1 \mathrm{ml}$ of the plant extract was place in a boiling tube wrapped with foil paper and $1 \mathrm{ml}$ of Folin-Ciocalteu's solution was added to $1 \mathrm{ml}$ of the plant extract followed by $1 \mathrm{ml}$ of $7.5 \%$ sodium carbonate solution. The mixture was adjusted to $30 \mathrm{ml}$ with deionized water after $3 \mathrm{~min}$. shaken vigorously and allowed to stand for 90 minutes. The absorbance was taken at $765 \mathrm{~nm}$ using a spectrophotometer (UV-Visible Spectrophotometer, Jenway-6705) and the total phenolic content was expressed as milligrams of gallic acid equivalent (GAE) per g of extract.

\section{Determination of total flavonoid content}

Total flavonoid content was determined by modifying a method earlier described by Chandra et al. using rutin as standard ${ }^{18}$. Briefly, $1 \mathrm{ml}$ of $2 \%$ $\mathrm{AlCl}_{3}$ solution (in ethanol) was added to $1 \mathrm{ml}$ of the extract solution. The mixture was shaken vigorously and incubated at room temperature for $15 \mathrm{~min}$, after which the absorbance was measured at $430 \mathrm{~nm}$. The total flavonoids content was expressed in mg Rutin Equivalent /g extract.

\section{DPPH radical scavenging activity}

The free radical scavenging activity of the extract and the control was carried out spectrophotometrically using 1,1-diphenyl-2-picryl hydrazyl (DPPH) as described by Ayoola et al., ${ }^{20}$ with slight modification. Briefly, $2 \mathrm{~cm}^{3}$ of $0.1 \mathrm{mM}$ DPPH was placed in a test tube containing different concentrations of each of the extract $(0.01-0.2$ $\mathrm{mg} / \mathrm{ml})$. The mixture was incubated in the dark for $30 \mathrm{~min}$. after which the absorbance of the resulting solution was taken at $517 \mathrm{~nm}$ using methanol as blank and ascorbic acid (0.002 to $0.04 \mathrm{mg} / \mathrm{ml})$ was used as standard. All determinations were carried out in duplicate and the radical scavenging activity was calculated as:

$\% D P P H$ scavenging activity $=\frac{A b-A a}{A b} \times 100$

Where: $A b=$ absorption of DPPH in methanol $\mathrm{Aa}=$ absorption of the solution containing the extract. The graph was plotted using Microsoft excel package and the $\mathrm{IC}_{50}$ values were determined by the logarithmic equations on the graph. Graphpad Prism 6 (Japan) was used to determine the mean \pm SD values. 


\section{ABTS cation scavenging activity}

The ABTS cation scavenging activity was determined according to the method described by Chandra et al., ${ }^{21}$. ABTS stock solution $(7 \mathrm{mM})$ was prepared in distilled water. The ABTS cation was prepared by adding 88 ul of $140 \mathrm{mM}$ potassium persulfate $\left(\mathrm{K}_{2} \mathrm{~S}_{2} \mathrm{O}_{8}\right)$ to $5 \mathrm{ml}$ of $A B T S$. The solution was stored in the dark for $16 \mathrm{~h}$ to stabilize it before use. The concentrated ABTS solution was placed in a cuvette and diluted with cold ethanol to a final absorbance of 0.700 at $734 \mathrm{~nm}$ (solution was heated at $37^{\circ} \mathrm{C}$ for $4 \mathrm{~min}$. after which absorbance was recorded). The total scavenging capacities of the extract/control were quantified by addition of $1000 \mu \mathrm{L}$ of ABTS to $1000 \mu \mathrm{L}$ and $50 \mu \mathrm{L}$ of each plant extract $(1 \mathrm{mg} / \mathrm{ml})$. Ascorbic acid $(0.04$ and $0.002 \mathrm{mg} / \mathrm{ml})$ was used as standard. The ABTS scavenging activity was calculated using the following formula:

$\%$ ABTS radical scavenging activity $=\frac{A b-A a}{A b} \times 100$

Where: $A b$ is absorbance of ABTS radical + ethanol, Aa is the absorbance of ABTS radical + sample extract/standard.

\section{RESULTS AND DISCUSSION}

The preliminary phytochemical screening revealed the presence of flavonoids, phenolics alkaloids, terpenoids and saponins in the extracts (Table 1).

Table 1: Phytochemical screening of Raphia hookeri leaf and epicarp

\begin{tabular}{cccc}
\hline S/N & Phytochemical & $\begin{array}{r}\text { Epicarp } \\
\text { Extract }\end{array}$ & $\begin{array}{c}\text { Leaf } \\
\text { Extract }\end{array}$ \\
\hline 1 & Phenolics & + & + \\
2 & Flavonoids & + & + \\
3 & Alkaloids (Meyer's Test) & + & + \\
4 & Saponins (froth test) & + & + \\
5 & Terpenoids (Salkowski test) & + & + \\
\hline
\end{tabular}

Key: + = present; - = absent

This was followed by the quantitative analysis (Total phenolic and flavonoid contents) of the extract. Amongst other pharmacological properties, high concentration of plant phenolics and flavonoids has been previously correlated with high antioxidant activity ${ }^{14,21}$. The total phenolic content and total flavanoid content of Raphia hookeri leaf and epicarp extracts were determined using the standard calibration curves shown in Fig. 1 and the results are shown in Table 2.

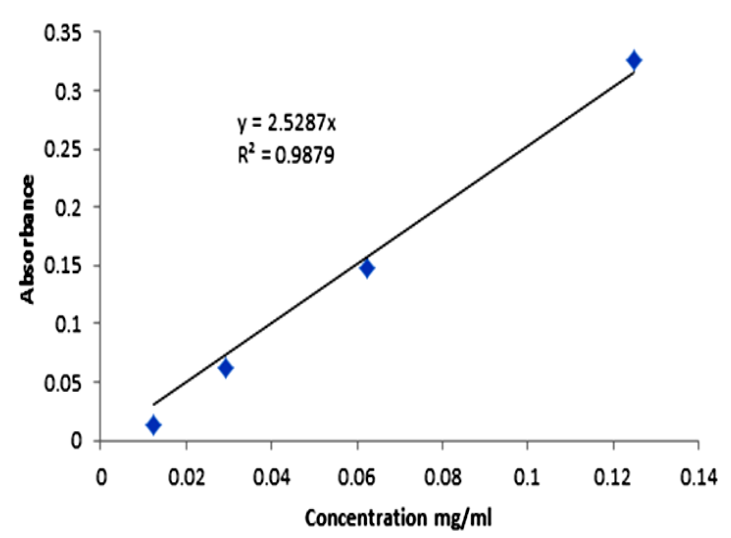

Fig. 1a. Gallic acid calibration curve for Total Phenolic Content Determination

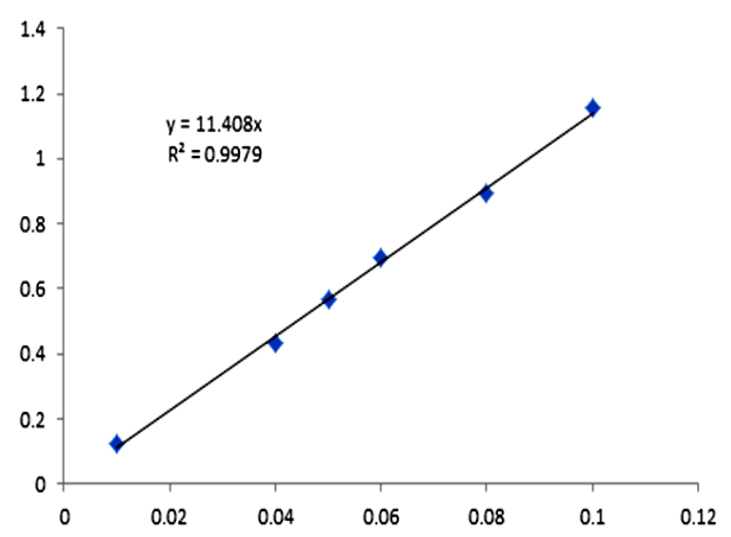

Fig. 1b. Rutin calibration curve for Total Flavonoid Content Determination

Table 2: Quantitative phytochemical content of Raphia hookeri leaf and epicarp extract

\begin{tabular}{lcc}
\hline $\begin{array}{l}\text { Phytochemical } \\
\text { Content }\end{array}$ & $\begin{array}{c}\text { Epicarp } \\
\text { Extract }\end{array}$ & $\begin{array}{c}\text { Leaf } \\
\text { Extract }\end{array}$ \\
\hline${ }^{*}$ Total phenolic & $459.917 \pm 30.405$ & $457.805 \pm 25.035$ \\
content (mg/g GAE) & & \\
${ }^{*}$ Flavonoid & $97.660 \pm 4.983$ & $351.170 \pm 22.950$ \\
content mg/g RE & & \\
\hline
\end{tabular}

*Values represent means \pm standard deviation of triplicate determinations

The total phenolic content of Raphia hookeri epicarp extract is slightly higher than that of the leaf and also higher than $39.73 \mathrm{mg} \mathrm{GAE} / \mathrm{g}$ extract which was recently reported in Raphia hookeri leaf extract by Dada et al.,22. A similar trend was also observed for the flavonoid content. The difference might be as a result of the different extraction procedures and solvents employed in both experiments in addition to possible ecological variation in the different plants employed. Consumption of food rich in phenolics (which include flavonoids) and their direct application 
is known to prevent the onset of cancer, inflammatory diseases and degenerative health conditions such as hypertension and dementia amongst others ${ }^{23}$. The oxidative stress which accompanies malaria infection ${ }^{24}$ and the current global increase concurrent administration of herbal decoctions with orthodox drugs $^{25}$ are valid basis for the inclusion of antioxidant extracts in such combinatorial malaria treatment. The phenolic content of Raphia hookeri leaf and epicarp extracts puts the plant in the class of extracts which could be examined this regard. Furthemore, the notable presence of alkaloids as confirmed by the phytochemical screening a suggests a predominant presence of alkaloids which have a long history of wide pharmaceutical efficacy ${ }^{26}$. Hence, this study reveals Raphia hookeri leaf and epicarp extracts as a new bio-resources which could be investigated for possible inclusion in diverse medicinal application. The antioxidant potential of Raphia hookeri leaf and epicarp extract was quantitatively evaluated and compared by employing the 1,1-diphenyl-2picryl hydrazyl radical (DPPH) and 2,2-azino-bis (3-ethylbenzthiazoline-6-sulfonic acid) (ABTS) cation assays using ascorbic acid as positive control (Figure 2a,b).

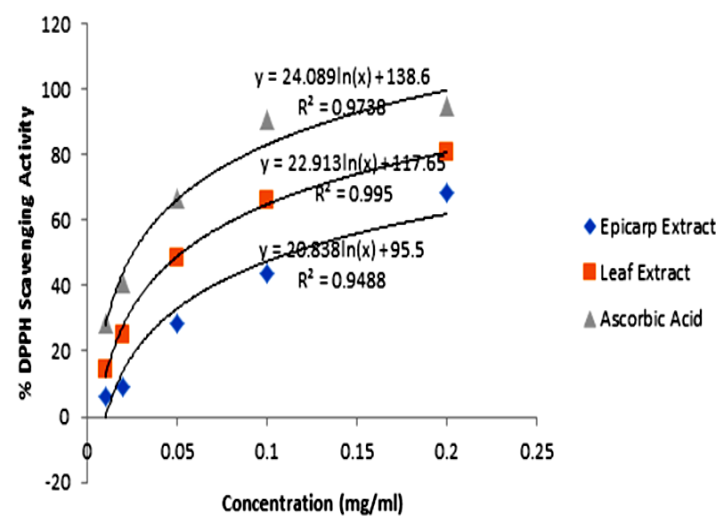

Fig. 2a. DPPH radical scavenging activity of Raphia hookeri leaf and epicarp extracts

The $\mathrm{IC}_{50}$ values obtained for extracts of Raphia hookeri leaf and epicarp in the DPPH assay were $0.0523 \mathrm{mg} / \mathrm{ml}$ and $0.1126 \mathrm{mg} / \mathrm{ml}$ respectively while that of the ascorbic acid control (at a lower concentration) was $0.0252 \mathrm{mg} / \mathrm{ml}$. Since the total phenolic content of the leaf and the epicarp are comparable, the higher flavonoid content of the leaf definitely contributed to its higher ability to scavenge free radicals. Comparing the $\mathrm{IC}_{50}$ value of the leaf with the report by Dada et al., (2017), it could be inferred that extraction methods and solvents employed, as earlier stated, go a long way in influencing the ability of extracts to scavenge free radicals.

The ABTS assay was also used to compare the antioxidant potential of the extracts. It is also worthy of note that both extracts exhibited similar ability to scavenge the ABTS cation in the two concentrations employed (Figure 2b).

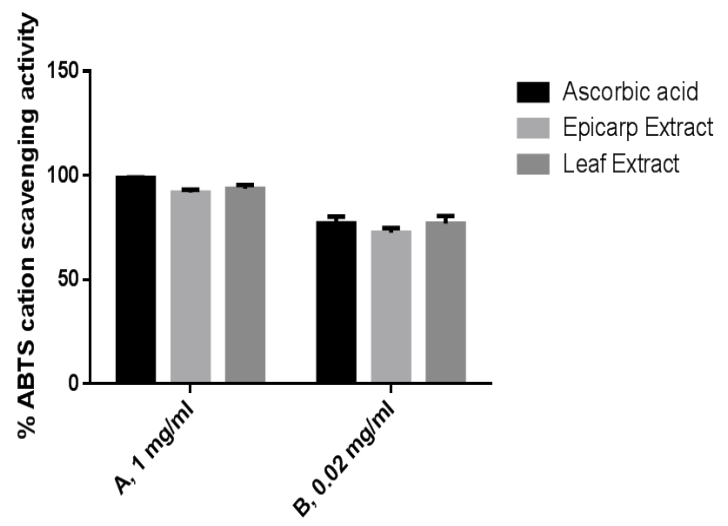

Fig. 1b. ABTS cation scavenging potential of Raphia hookeri leaf and epicarp extract; Values represent means \pm standard deviation of triplicate determinations. Ascorbic acid concentration for $A$ and $B$ are 0.04 and $0.002 \mathrm{mg} / \mathrm{ml}$ respectively

Although not as efficient as the ascorbic acid control, employing Raphia hookeri leaf and epicarp extract as a source of antioxidants will not contribute any threat to food security amongst other benefits. The epicarp of this plant is generally regarded as waste and does not have any prominent use at the moment. Hence, its use as an antioxidant bio-resourse will also contribute to effective waste management.

\section{CONCLUSION}

This work provides a basis for different bioassay guided fractionation, isolation and characterization of medicinal compounds from Raphia hookeri leaf and epicarp extracts which could in turn provide new drug leads for useful application in phytomedicine.

\section{ACKNOWLEDGEMENT}

The authors are grateful to Landmark University Management for provision of powered laboratory facilities which enhanced the execution of this study. 


\section{REFERENCES}

1. Pham-Huy, L.A.; He, H.; and Pham-Huy, C. Int J Biomed Sci., 2008, 4(2), 89-96.

2. Kavishe, R.A.; Koenderink, J.B.; Alifrangis, M. Malaria., 2017, 284(16), 2579-2591.

3. WHO : World malaria report Geneva: World Health Organization., 2015,

4. Percário, S.; Moreira, D.R.; Gomes, B.A.Q.; Ferreira, M.E.S.; Gonçalves, A.C.M.; Laurindo, P.S.O.C.; Vilhena, T.C.; Dolabela, M.F. and Green, M.D. Int J Mol Sci., 2012, 13(12), 16346-16372.

5. Ibegbulem, C.O.; Igwe, C.U.; Okwu, G.N.; Ujowundu, C.O.; Ayalogu, E.O. Food Chem., 2013, 138 (2-3), 1616-1620.

6. Umoren, S.A.;Obot, I.B.;Ebenso, E.E.;Obi-Egbedi, N.O. Desalination., 2009, 247(1-3), 561-572.

7. Okoye, C.C.; Onukwuli, O.D.; Okey-Onyesolu, C.F. J. King Saud Univ.-Sci., 2017, doi. org/10.1016/j.jksus.2017.11.004

8. Umerie, S.C. Bioresource Technology., 2000, 75(2), 167-169.

9. Inyinbor, A.A.; Adekola, F.A.; Olatunji, G.A. S. Afr. J. Chem., 2016, 69, 218-226.

10. Edem, D.O.; Eka, O.U.; Ifon, E.T. Food Chem., 1984, 15(1), 9-17.

11. Sonibare, M.A.; Moody, J.O.; Adesanya, E.O. J. Ethnopharmacol., 2009, 122(2), 268-72.

12. Obuotor, M.; Onajobi, F.D. Fitotherapia., 2000, 71(2), 190-192.

13 Oluyori, A.P.; Olatunji, G.A.; Atolani, O. Pak J Sci Ind Res Ser A: Phys Sci., 2013, 56, 57-58.

14. Oluyori, A.P; Olatunji, G.A. J. Intl. Res.med Pharm. Sci., 2016, 6(4),157-164.

15. Oluyori, A.P.; Shaw, A.K.; Preeti, R.; Sammajay R.; Atolani, O.; Olatunji, G.A.; Fabiyi, O.A.; Nat. Prod. Res., 2016, 30(18), 2125-2129.
16. Oluyori, A.P.; Shaw, A.K.; Olatunji, G.A.; Preeti, R.; Sanjeev, M.; Dipak, D.; Ashish, A.; Sama, A.; Puli, S.R. Nutrition and Cancer., 2016, 68(8), 1330-1337.

17. Zhao, B.; Hall, C.A. Food Chem., 2008, 108(2), 511-8.

18. Chandra, S.; Khan, S.; Avula, B.; Lata, H.; Yang, M. H.; EISohly, M. A.; Khan, I. A. Evid based Complement Alternat Med., 2014, 253875.

19. Harborne, J.B. Phytochemical Methods: A Guide to Modern Techniques of Plant Analysis., 1973.

20. Ayoola, G.A.; Coker, H.A.B.; Adesegun, S.A.; Adepoju-Bello, A.A.; Obaweya, K.; Ezennia, E.C.; Atangbayila, T.O. Trop J Pharm Res., 2008, 7(3), 1019-1024.

21. Saeed, N.; Khan, M.R.; Shabbir, M. BMC Complement Altern Med., 2012, 12, 221.

22. Dada, F.A.; Oyeleye, S.I., Ogunsuyi, O.B.; Olasehinde, T.A.; Adefegha, S.A.; Oboh, G.; and Boligon, A. A. J Tradit Complement Med., 2017, 7(4), 494-500.

23. Ozcan, T.; Akpinar-Bayizit, A.; Yilmaz-Ersan, L. and Delikanli, B. Intl. J. Chemical Engineering and Applications., 2014, 5(5), 393-396.

24. Redan, B.W.; Buhman, K.K.; Novotny, J. A.; Ferruzzi, M.G. Adv Nutr., 2016, 7(6), 10901104.

25. Adepiti, A.O.; Elujoba, A.A.; Bolaji, O.O. Pharmaceutical Biol., 2016, 54(10), 22982303.

26. Alves de Almeida, A.C.; Meira de-Faria, F.; Dunder, R.J.; Manzo, L.P.B.; Souza-Brito, A.R.M.; and Luiz-Ferreira, A. Evid based Complement Alternat Med. 2017, https://doi. org/10.1155/2017/8528210. 